\title{
WORDPLAY IN THE ENGLISH LANGUAGE AND ITS TRANSLATION IN FILM SCRIPTS
}

Summary. Many recent studies have focused on such notion as wordplay in the English language since this phenomenon has become one of the most popular means of humor in film scripts. However, few investigations have focused on analyzing the typological aspect of wordplay in modern English language and especially the methods of translation in the Ukrainian language. The major tasks of this study are to provide the definition of wordplay, and to analyze its translation in the dialogues from English into Ukrainian in film scripts. Different definitions of the term have been studied and the analysis of them is provided. Also, the data indicates the most productive ways of wordplay translation.

Keywords: wordplay, pun, classification, translation, film script.

Шевченко А.O.

Чорноморський національний університет імені Петра Могили

\section{ГРА СЛІВ В АНГЛІЙСЬКІЙ МОВІ ТА ЇЇ ПЕРЕКЛАД У ТЕЛЕСКРИПТІ}

\begin{abstract}
Анотація. Гра слів е досить складним та розповсюдженим явищем як в літературі, так і в лінгвістиці. Зважаючи на брак комплексного аналізу стосовно даної теми, явище гри слів потребуе поглибленого та розширеного вивчення - з урахуванням його прагматики, складної структури та специфіки семантичного аспекту. Варто приділити увагу проблемі перекладу гри слів, адже це питання актуальне і єдиної вірної методики перекладу гри слів досі не існуе. Аналізуючи феномен гри слів, необхідно зосередити увагу на його переклад українською мовою. Переклад, як відомо - це не лише відтворення змісту оригіналу засобами іншої мови, але і зв'язок між культурами різних країн. Це один з найедективніших шляхів обміну науковими, культурними, естетичними та філософрськими цінностями різних країн і континентів. Безліч недавніх досліджень було зосереджено на понятті гри слів в англійській мові, оскільки це явище стало одним з найпопулярніших засобів гумору в кіносценаріях. Проте лише деякі дослідження включають в себе аналіз типологічних аспектів гри слів у сучасній англійській мові та, головним чином, зосереджуються на способах перекладу українською мовою. Основними завданнями даного дослідження є резюмування визначення гри слів та аналіз перекладу діалогів з англійської на українську мову в сценарії телескрипту. Переклад даного поняття - це складний процес, що складається з декількох етапів, а саме: ідентифікація гри слів у тексті оригіналу, пошук мовних засобів для передачі гри слів іншою мовою і завершальний етап - створення тексту перекладу. Різні визначення поняття були досліджені та проаналізовані. Також ці дані вказують на найбільш продуктивні способи перекладу каламбурів. Визначено, що без значних труднощів можливо перекласти гру слів, коли переклад здійснюеться на генеалогічно-споріднену мову або завдяки зв'язку з позамовною реальністю. В цьому випадку гру слів на основі полісемії можна відтворити з незначними втратами навіть у генеалогічно-неспорідненій мові. Зазвичай використовуеться дослівний переклад для відтворення гри слів українською мовою. Встановлено, що найчастіше використовуються наступні способи перекладу гри слів: збереження гри слів при перекладі та заміна на вираз, який не містить гру слів. Визначена важливість адекватності та еквівалентності перекладу, адже від цього залежить наскільки зрозумілим буде першопочатковий сенс після перекладу. У контексті дослідження для ідентифікації гри слів використовуються телескрипти та відео ряд мовою оригіналу.
\end{abstract}

Ключові слова: гра слів, каламбур, класифікація, переклад, телескрипт.

Tntroduction. The increasing interest in

foreign film production has heightened the need for a precise research on translation of different stylistic devices. Of particular interest and complexity are those that can only be understood through the context, for example, wordplay and pun correspondingly. The opinions have separated and the relevant question is whether to consider the wordplay and pun as interchangeable notions. Some scholars, like Leppihalme (1997), treat pun as a separate subcategory of wordplay, whereas others, like Delabastita (1996) and Redfern (1985), use the two abovementioned terms interchangeably. The studies of Gridina (1996), Tymchuk (2003) and Vynogradov (2001) distinguish the terms of wordplay and pun, therefore different definitions of wordplay and pun exist. Further investigations of Vlahov (1980), Kolesnichenko (1984), and Suhorukov (2003) observe the general features of pun in particular. Fedorov (2002) regards the translation types of pun. In this research Dirk Delabastita's point of view is followed and terms wordplay and pun are considered to be equal.

However, few attempts have been made to form an accurate and complex classification of wordplay. It is important to consider all the peculiarities of this stylistic device to maintain the original meaning, style, and the norms of literary language. In order to conduct a relevant research, the term "wordplay" and its features require a thorough study.

The purpose of this paper is to correlate the notions of "wordplay" and "pun" and to observe the coherent and complex translation methodology of pun phenomenon and its implication based on the original script of TV series "Friends" in the English language and its translation into Ukrainian. This American TV series was released in 1994 and quickly became popular not only in the United States, but all over the world. It is chosen for consideration due to the multiple usage of wordplay in its script. 
Methods. Many linguistic methods are used in this research. Etymological method is applied to establish the origin of the concept of "wordplay". A comparative one is used for correlation of wordplay and pun in the script in the English and Ukrainian languages. Stylistic analysis is involved to identify the wordplay as the dominant stylistic device in the script of this TV series. Contextual method is implemented to describe the context of situations where wordplay is used. Also, a quantitative method is applied to determine the amount of the used wordplay in the script.

Results and discussion. The phenomenon of wordplay has been analyzed as a dominant stylistic device in TV series "Friends" script. This research of wordplay and its translation has led to the following results. Different theories of the term origin are given and approaches of various linguists are described. Possible ways of translation together with the examples from TV series "Friends" script have been investigated as well as the issue of transferring the wordplay into Ukrainian language.

This paper focuses on the correlation of the terms "wordplay" and "pun" and summarize various ways of translation. After comparing definitions given by different linguists, it is claimed that "wordplay" and "pun" may be used interchangeably. The core semantics, considering the wordplay notion is shown in Dirk Delabastita's definition that is dense and comprehensive, "Wordplay is the general name for the various textual phenomena in which structural features of the language(s) are exploited in order to bring about a communicatively significant confrontation of two (or more) linguistic structures with more or less similar forms and more or less different meanings. Semantically, several meanings are activated by identical or similar forms in a text" [2]. In this definition structural features and the purposes of the phenomena are covered and the correlation of similar forms and different meanings is mentioned. That is why Delabastita's point of view is followed and the terms wordplay and pun are considered to be equal.

To observe the coherent and complex methodology of wordplay translation the analysis has been conducted. Throughout a big variety of existing translation methods, the most suitable for my research are the following 5 methods, which were distinguished by Dirk Delabastita.

The $\underline{\text { FIRST }}$ is pun $=>$ pun: the source-text pun is translated by a target-language pun, which may be more or less different from the original wordplay in terms of formal structure, semantic structure, or lexical function.

Here is the example from the TV series "Friends". Situation - Rachel is nervous and others try to calm her down:

"MONICA: Just breathe, breathe.. that's it. Just try to think of nice calm things...

PHOEBE: (SINGS) Raindrops on roses and rabbits and kittens, (RACHEL AND MONICA TURN TO LOOK AT HER)..bluebells and sleighbells andsomething with mittens... La la la la...

RACHEL: I'm all better now. [6; 9]

M.: Ти дихай, думай про щось приємне $i$ спокійне.

Ф.: Дощові краплини на трояндах $i$ кумедні вуса на котах, дзвонять дзвони веселкові ластівками на дротах, щось там зі струною ma-pa-pa

P.: Мені вже набагато легше." [10; 1 season, 1 series]

So, the lexical pun is built on antonymy and the translation is shortened. The purpose for this dialogue is it not to translate each word, but to convey the meaning.

The SECOND, is pun => non-pun: the pun is renThe $\underline{\boldsymbol{S E C O N D}}$, is pun => non-pun: the pun is rendered by a non-punning phrase which may salvage both senses of wordplay but in a nonpunning conjunction, or select one of the senses at the cost of suppressing the other; of course, it may also occur that both components of the pun are translated 'beyond recognition'. Situation - Joey is going to audition for medicine commercial:

"CHANDLER: Do you know which one you're gonna be?

JOEY: No, but I hear lyme disease is open, so... [crosses fingers]

CHANDLER: Good luck, man. I hope you get it. JOEY: Thanks. [6;9]

Ч.: А ти знаєш ким будеш?

Дж.: Ні, але я чув, недавно відкрили хворобу Лайлna,

Ч.: Усnіху, старій. Сподіваюсь ти ӥ̈ підчепищ.

Дж.: Длкую." [10; 1 season 9 series] "

Thus, lexical pun is presented with a help of polysemantic collocation "get something". It is possible to get the role and to get the disease. In Ukrainian translation the pun is lost, because the chosen word "підчепиш" is related to the medical sphere and is not applied to the word "role". The translation is shortened and one of the senses is selected at the cost of suppressing other.

The $\underline{\text { THIRD }}$ method is pun $=>$ related rhetorical device: the pun is replaced by some wordplay related rhetorical device (repetition, alliteration, rhyme, referential vagueness, irony, paradox, etc.) which also aims to recapture the effect of the source-text pun. Situation - Ross and his ex-wife are in hospital and argue about their child's name.

"CAROL: -if it's a boy, Minnie if it's a girl.

ROSS: ...As in Mouse?

CAROL: As in my grandmother.

ROSS: Still, you- you say Minnie, you hear Mouse. Um, how about, um.. how about Julia? [6; 9]

К.: Міні, якщо дівчинка.

$P .:$ Gк Мишкy?

К.: Як мою бабусю.

P.: Якщо сказати Міні, то всі думають про Мишку. Може назвати Джулія? [10; 1 season 2 series]

So, phonetic assonance is used to make pun. The main point is how the name Minnie and cartoon character Minnie Mouse sound similar. Full translation is presented.

The FOURTH method is PUN => ZERO: the portion of text containing the pun is simply omitted. Situation - Chandler and Ross discuss Rachel's affair: "CHANDLER: Ah, it's just a weekend, big deal! ROSS: Wasn't this supposed to be just a fling, huh? Shouldn't it be... [makes flinging motions with hands] flung by now? [6, 9]

Ч.: Два дні, подумаєш!

Р.: Чи не був ие розгул? Мало вам розгулу mym?» [10; 1 season 12 series] 
Thus, the polysemantic word "fling", that is used both as a noun and verb, loses it is initiative double meaning. The shortened translation simplifies the dialogue and omits the pun.

The FIFTH method is PUN ST $\Rightarrow$ PUN TT: the translator reproduces the source-text pun and possibly its immediate environment in its original formulation, i.e. without actually 'translating' it. Situation - Joey tries to think up a pseudonym: "CHANDLER: How about Joey... Pepponi? JOEY: No, still too ethnic. My agent thinks I should have a name that's more neutral. CHANDLER: Joey... Switzerland? [6; 9] Ч.:Може Джої Паппоні?

Дж.:Нi, звучить та само по-італійському. Мій агент каже, що псевдонім має бути нейтральний.

Ч.:Джої Швейцарія?» [10; 1 season 21 series]
In this piece lexical pun uses the names of the country. As Joey looks for something neutral, Chandler suggests "Switzerland", because the country is known to remain neutral, when it comes to politics.

Thus, the systematization of 120 examples of wordplay confirms that the most widespread type of wordplay translation is the first one (pun => pun) and translators attempt to save the wordplay and humorous effect where it is possible.

Conclusion. This paper states that the notions of wordplay and pun may be considered equal and the results of this research are consistent with the findings of available studies. The research also presents different techniques used to translate wordplay into Ukrainian. The results are illustrated by examples from TV series "Friends". Further research on wordplay and its translation into Ukrainian is advocated.

\section{References:}

1. Chiaro D. The Language of Jokes: Analysing Verbal Play. London : Routledge, 1992.

2. Delabastita D. Wordplay and Translation: Essays on Punning and Transla-tion. Manchester : St. Jerome Publishing, 1996.

3. Gridina T.A. (1996). Yazyikovaya igra: stereotip i tvorchestvo [Language game: the stereotype and creativity]. Ekaterinburg : Ural.

4. Leppihalme R. Sanaleikit kääntäjän päänvaivana. In Korimo-Girod, 1997.

5. Redfern W. Puns. Oxford : Blackwell, 1985.

6. Script of TV series "Friends" in English. URL: http://www.angelfire.com/tv/chocgal/scripts.html

7. Suhorukov O.M. (2003). Lektsii i osnovyi perevoda [Lectures and basics of translation]. Kyiv: Osnova.

8. Taxonomy of Wordplay. URL: http://www.questrel.com/records.html

9. TV series "Friends" in English. URL: http://friends-online.su/

10. TV series "Friends" in Ukrainian. URL: http://serialsonline.net/serials/Friends-ukraine-online.html

11. Tymchuk O.T. (2003). Semantyko-stylistychne yavyshche hry sliv v ukrainskii movi [The semantic and stylistic phenomenon of play on words in the Ukrainian language]. Kyiv : Lybid.

12. Vlahov S.N., Florin S.K. (1980). Neperevodimoe v perevode. [Untranslatable in translation]. Moscow : International relations. 